\title{
COMPARISON OF VAT SYSTEMS IN RUSSIA AND CHINA
}

\author{
Olga Karpova \\ Ural Federal University; olmkarpova@gmail.com \\ Igor Mayburov \\ Ural Federal University, Far Eastern Federal University; mayburov.home@gmail.com
}

\begin{abstract}
This article analyzes the tax system in Russia and China, with the focus on the value-added tax (VAT). Since Russian-Chinese integration processes are fast growing, the subject has gained currency. The trend towards closer cooperation is due on the one hand to the reorientation of Russia from Europe to Asia, and on the other hand, the economic rise of China and the development of the large-scale New Silk Road project (NSR). Such changes require better aligned legislations of the neighboring states. Besides, China can boast considerable experience in providing preferences to exporting companies, while in Russia this direction is still insufficiently developed. In addition, the mechanism of indirect taxation in the two countries has little in common. The applied method of comparative analysis has identified the strongest and the most vulnerable elements of Russian and Chinese VAT systems. The evaluation embraced the governance structure of the tax authorities, legislative basis, tax rates, categories of VAT payers, and export VAT refund scheme. The results have pointed to a twofold nature of the Chinese VAT system, which stimulates the activity of the residents across the country, while the foreign investors are encouraged only in certain areas. The Russian VAT system, on the contrary, is quite standardized, although export promotion tools are underutilized. The final part of the article describes the key findings of the comparative analysis.
\end{abstract}

Keywords: tax system, value added tax, VAT system, export VAT, VAT refund

\section{Introduction}

The system of indirect taxation in China remained ambivalent through 2016. The commodity sector was liable to VAT and the business tax (BT) was levied on the service sector. In 2012, a tax reform was launched, that stipulated that all the service organizations were supposed to gradually switch from BT to VAT. In the first phase of its application in the new sectors, VAT was introduced as a pilot program in some provinces, but then the tax gradually covered the whole territory of the country. The pilot program of the transition to VAT was successfully completed by 1 May 2016, and BT for the service sector was abolished. A characteristic feature of the VAT system in China is that uniform legislative provisions are treated differently in different provinces. Moreover, local authorities may adopt additional provisions which can simplify or complicate the taxpayers' life. A striking example of such behaviour is the city of Yiwu which is not included in the special economic zone (SEZ), but the local authorities provide tax benefits for exporting companies on an equal footing with the SEZ. Understanding the territorial differences in taxation is especially important for foreign companies if they plan to open a legal entity in China.

In Russia the taxation system was built in the image and likeness of Europe. In 1992, the Law on Value Added Tax was adopted and applied through 2001, when the Tax Code of the Russian Federation came into effect. The Russian legislation set uniform requirements for calculation and payment of VAT throughout the country, and the local authorities could not impose their own regulations. With reference to VAT, the legislation has undergone no significant changes since 2001.

It is worth noting that the Chinese market is attractive to foreign companies, but sufficiently closed. In particular, exporters of food products from Russia face a lengthy procedure of verification at the border carried out by the Chinese customs. In view of the limited duration of storage, most goods become worse and exporters bear substantial losses. This requires an integrated approach: conclusion of intergovernmental agreements, on the one hand, and support for exporters, on the other hand.

\section{Methods}


The study examines the current state of the VAT systems in Russia and China through a comparative analysis which allows for reviewing the two systems at the more general level without resorting to narrow specialization (Della Porta and Keating, 2008). The objects of research are VAT systems in Russia and China compared in the following areas: public authorities, legislative basis, tax rate, VAT payers, and refund of export VAT. To enhance the quality of results, some criteria were chosen that most likely support reliable information and are seen more in line with the hypothesis. There was adopted a hypothesis that VAT policy in China is more innovative in comparison with Russia. The time period for research is for 1991-2016, when the basic regulating documents concerning VAT were adopted. Special attention is paid to the current state of affairs.

The article is built on a "point-by-point" (Walk, 1998) structure, that is, for each of the stated parameters it provides information on the VAT system in one country, and then gives a description of another country. After the parameters being discussed, the article describes the experience of China in the application of VAT as an element of export promotion.

\section{Research}

\section{Public authorities}

Taxation in China is regulated by the State Administration of Taxation (SAT), the Ministry of Finance (MOF) and the local tax authorities. In addition, other interested ministries and departments can be involved. The Ministry of Finance is the national executive authority of the Central People's Government, which implements macro-and microeconomic policies and develops plans of the annual national budget. In the jurisdiction of MOF is the State Administration of Taxation (SAT), the highest tax authority responsible for developing tax legislation, consulting the State Council on Taxation, developing the procedures for implementation of innovations and controlling local tax bureaus. Local tax bureaus in turn collect taxes at the local level and counsel taxpayers.

In Russia this direction is supervised by the Ministry of Finance (MOF), the Federal Tax Service (FTS) and territorial tax authorities. On the face of it, the system of the two countries are similar, as MOF in Russia is the Federal body of executive power carrying out a unified state financial policy and general management of the finance in the country. Also, FNS refers to the executive branch and territorial tax offices overlap with those of the FNS in the regions.

One of the main FNS functions is the registration of legal entities and individual entrepreneurs. To open a company in China a person must get permission from the Ministry of Commerce (MOFCOM) and the State Administration of Industry and Commerce (SAIC). In addition, if the company is among the priority directions for development of Chinese economy, then additional permission to work is needed from the National Development and Reform Commission (NDRC). Small business is served by the Commission's provincial offices (Zdorikova, 2016).

Local tax authorities also operate in the different mode. In Russia, the territorial tax bodies are essentially agents of FNS policies and convey the essence of the Federation policy to payers, while in China tax bureaus strongly depend on the provinces. Orders of the parent bodies are not always interpreted in the same way, and the tax bureaus are sufficiently free to formulate their own line of action when exercising their functions. General recommendation for entrepreneurs in China is consulting a local tax office before starting a business (GWA, 2013).

\section{Legislative basis}

In Russia, tax legislation is sufficiently standardized with the tax code (TC of RF) as the main document. Value added tax is described in the chapter 21. The Tax Code of the Russian Federation establishes uniform rules for all payers of VAT regardless of the region. To date, a project of tax reform, which implies an increase in the basic VAT rate to $22 \%$, is being developed.

In the People's Republic of China the Temporary Regulations of the People's Republic of China on Value-Added Tax remain valid as the main document. In addition to this provision, there are ten more normative-legal acts concerning VAT, issued by different departments. In 2016, all China's taxpayers moved from business tax (BT) to VAT. The reform mainly covered services, intangible assets and immovable objects, with the main purpose of reducing the tax burden across all industries.

Tax rates and VAT payers

VAT rates in Russia are the same for entities that follow the common system of taxation. When the tax is being calculated, the size of the authorized capital and the revenues are not taken into account. Businesses can avoid paying VAT just by following a different taxation system which involves payment of other taxes (for example, the simplified taxation system). 
As regards the People's Republic of China, the VAT taxpayers are divided into two categories: general taxpayers and small taxpayers (Guoshuihan, 2002). A VAT rate for general taxpayers can be equal to $0 \%, 6 \%, 11 \%$, or $17 \%$, while small taxpayers operate at the rate of $3 \%$, did not have the right to issue VAT invoices and export goods and services. In 2012, China issued the so-called Notice No. 227 (Shenzhen State tax letter, 2012), which establishes the conditions for inclusion of the companies into a specific category for new and existing companies, and also introduces a list of requirements for the transition from one taxpayer category to another.

Rate of $17 \%$ is common for goods (services) of the People's Republic of China and imported goods, including the provision of services for the repair, renovation and recycling, as well as the leasing of movable property. The sale or importation of goods of first necessity (for example, agricultural products, water, and gas) was liable to $13 \%$ rate until 1 July 2017 , and is $11 \%$ rate since 1 July 2017. Also, this rate is levied on freight services, postal services, basic telecommunications, construction services, real estate leasing and sale, and transfer of land rights. The rate of $16 \%$ is for certain types of telecommunication services, financial services, modern service (except the lease), household services, and sale of intangible property (except the transfer of right to use on land). A zero rate is applied upon export of goods; exports of services for the repair, modernization and processing; international freight services, transport of the spacecraft; export services that are completely consumed outside of China (research and R\&D; contracts for power efficiency; services on design; production and distribution of radio, movies and television; delivery of software; design and testing of architecture, etc.

In Russia, the VAT payers are all legal persons within the common system of taxation. The organization independently once a year determines the mode of taxation it will follow. The following options are available: general taxation system (GTS), simplified tax system, uniform tax on imputed income, single agricultural tax, and patent system of taxation. There are three VAT rates. The overall $18 \%$ rate applies to goods and services not included in the list of taxable assets at the rate of $10 \%$ or $0 \%$. The $10 \%$ rate is for food products; goods for children; periodicals; book products related to education, science and culture; medical goods and some imported goods. A zero rate applies to exports and realization of goods (works and services: on the international freight of goods, in the area of space activities, precious metals, built ships, as well as a number of freight services).

\section{Refund of export VAT}

The category of taxpayers entitled to a refund of export VAT is of a particular interest. In Russia, the full refund of export VAT can be granted to any taxpayer who can confirm the export operation. In China, when confirming export transaction, the company can get a discount on the VAT it paid. The amount of discount varies depending on the product category.

In Russia, all export transactions are subject to the $0 \%$ VAT, but this zero rate should be confirmed by an exporter within 180 days from the date of registration of the export declaration. The following documents should be submitted to the tax office:

1. Contract (a copy of the contract) between the taxpayer and the foreign person on the supply of goods (supplies).

2. Customs Declaration (a copy) with the records of the Russian Customs authority.

3. Copies of transport, shipping and (or) other documents with the records of the Customs authorities of the places of departure, confirming export of goods.

4. Bank statement confirming the actual flow of revenues in the taxpayer Russian account from the sale of specified goods to a foreign person.

5. Mediation agreement (copy) if the sale of the product was transacted through the agent.

The list is not exhaustive and the tax service has the right to demand additional documents which certify the export operation. In addition, the exporter must be a resident of the Russian Federation and follow the general system of taxation. Depending on the amount of the VAT paid to the budget, the $10 \%$ or $18 \%$ rate may apply as a rate of return. Consideration of documents lasts up to three months. A positive decision is made by crediting of VAT amounts on the company's bank account or as repayment of fines. When payment is refused, there is VAT charge and payment of VAT amounts, as well as late charge.

In China, all export transactions are also subject to the 0\% VAT, but the amount reimbursed for the VAT already paid on the domestic market does not cover the costs of the exporter in full. The country applies the so-called VAT rebate system for various categories of goods (from $6 \%$ to $17 \%$ ). The Government developed the system to regulate the exports, for example, VAT refund is put under a ban for the items prohibited for export (musk, bezoar stones, copper, platinum, crude oil and diesel fuel). 
In this case, the exporter is only liable to the zero rate VAT when selling goods and services abroad, and not entitled to reimbursement of the tax already paid.

A general taxpayer company, registered in Mainland China, and a licensed exporter, accredited by the tax authorities and gaining currency earnings (probably offshore), can get a discount on VAT. Within 90 days from the date of registration of the export declaration, the exporter can apply for VAT discounts. The following original documents should be enclosed: customs declaration, invoice, packing list, export contract, internal invoices and invoices, documents from the bank confirming currency earnings, export insurance, and mediation contract if the sale of the goods was carried out through an agent. Additional documents may be requested, which must be provided by the 15 day of the month following the month of receipt of a request from the tax bureau.

On the basis of the submitted documents, the tax bureau classifies the exporter as a state, production or trading company. An exporter category directly affects the review period and decision making (from 1 to 6 months). A positive decision is made by crediting of VAT amounts on a company's banking account. When export operation is not confirmed, the transaction is recognized as domestic and VAT is paid in full.

\section{Results and Discussion}

The Chinese laws are sufficiently loyal towards residents, and the Chinese companies, regardless of the place of registration, are eligible for tax benefits, in particular, export VAT refunds. The foreign companies face serious limitations supported by bureaucratic procedures on the local level. For example, foreign companies cannot be registered as general taxpayers, which implies limited ability of VAT compensation and reduces the chances of cooperation with resident companies.

Thus, the Russian juridical entities wishing to enter the Chinese market usually invest in opening offices in China or open a company with $100 \%$ foreign capital, fully owned by a foreign entity (WFOE), or arrange a joint venture with the Chinese partners.

The agency is a simple form of legal entity in terms of registration. However, it only provides the company's presence in China and can carry out market research without commercial activities. The agency cannot enter into contracts and accept payments. Typically, this form of organization is beneficial for large consulting firms and marketing agencies.

The practice of joint ventures (JV) with China with the participation of foreign investors (up to $50 \%$ ) was rather popular among the Russian businessmen in the mid- 2000's. But the practice of joint ventures involves a number of risks such as theft of intellectual property, educating and training of future competitors, corruption of the Chinese top managers and board members, and forced placing of the business under actual control of the Chinese partners (as they are more knowledgeable about local realities) (Paulin, 2014). The post-crisis experience shows that the Chinese authorities are more interested in building major joint ventures in certain sectors (the main ones are processing industry, agriculture, high-tech production, production of exports, environmental protection, etc.). In addition, there was introduced a mandatory minimum amount of the authorized capital for JV - not less than 100 thousand dollars. The investor must contribute a certain amount to the development of business in China, and this is called "total investment" (TI) by the Chinese law. The TI cannot be less than the authorized capital, and therefore, the actual size of the authorized capital is defined at the stage of filing an application for registration of the company. The investor claims the amount of the planned investments, and the registration authority determines the amount of authorized capital (for example, when the TI is up to 3 million dollars, the authorized capital will amount to 7/10 from the TI; when the TI is from 3 to 10 million dollars, the authorized capital will not be less than $1 / 2$; with the TI from 10 to 20 million dollars - not less than $2 / 5$, etc.). For this reason, the Russian-Chinese joint ventures currently exist mainly at the level of major international projects, involving state-owned enterprises. Similar joint ventures may get bilateral tax preferences.

The most optional choice is a company with $100 \%$ foreign participation (WFOE). The main advantages of the WFOE is independence in decision-making, official possibility of doing business, converting profits in any currency and displaying it outside China, possibility of engaging in the import and export operations without a license, and the ability to protect intellectual property rights. However, the WFOE is strictly limited in the kinds of economic activities and cannot work in the areas that are not specified in the certificate of registration. Violations are punishable by fines or closure of the company.

The China's stringent bureaucratic legislation, which is artificially bureaucratic in many respects, sharply contrasts with the regulations in force in the territory of the special economic zones (SEZ), which include free economic zones (FEZ), export processing zones (or bonded zones), and 
experimental trade zones. These are territories of increased liberalization of laws, where tax and administrative stimuli are effectively applied. For example, a foreign company can get refunds on the export VAT only in the case of registration on the territory of the SEZ. The return rate ranges from 12 to $17 \%$. Moreover, in the first year of its operation the company shall be exempt from the income tax; for the second and third years, the rate is reduced to half - up to $7.5 \%$; for the next four-ten years, the rate is $15 \%$ (the rate for the rest of China can amount to $45 \%$ ). The process for registering a new company is maximally simplified and takes from one to one and a half weeks, while throughout the whole territory it can last from six months to one year.

In fact, the entire focus of the SEZ is on the foreign capital invested in the country. This design makes it easier to control the activities of foreign investors and allows for using the attracted investments for public purposes. Currently, the SEZs are the starting points on the map of the new Silk Road.

\section{Conclusions}

The Chinese laws are sufficiently loyal towards residents, and the Chinese companies, regardless of the place of registration, are eligible for tax benefits, in particular, export VAT refunds. The foreign companies face serious limitations supported by bureaucratic procedures on the local level. For example, foreign companies cannot be registered as general taxpayers, which implies limited ability of VAT compensation and reduces the chances of cooperation with resident companies.

Thus, the Russian juridical entities wishing to enter the Chinese market usually invest in opening offices in China or open a company with $100 \%$ foreign capital, fully owned by a foreign entity (WFOE), or arrange a joint venture with the Chinese partners.

The agency is a simple form of legal entity in terms of registration. However, it only provides the company's presence in China and can carry out market research without commercial activities. The agency cannot enter into contracts and accept payments. Typically, this form of organization is beneficial for large consulting firms and marketing agencies.

The practice of joint ventures (JV) with China with the participation of foreign investors (up to $50 \%$ ) was rather popular among the Russian businessmen in the mid- 2000's. But the practice of joint ventures involves a number of risks such as theft of intellectual property, educating and training of future competitors, corruption of the Chinese top managers and board members, and forced placing of the business under actual control of the Chinese partners (as they are more knowledgeable about local realities) (Paulin, 2014). The post-crisis experience shows that the Chinese authorities are more interested in building major joint ventures in certain sectors (the main ones are processing industry, agriculture, high-tech production, production of exports, environmental protection, etc.). In addition, there was introduced a mandatory minimum amount of the authorized capital for JV - not less than 100 thousand dollars. The investor must contribute a certain amount to the development of business in China, and this is called "total investment" (TI) by the Chinese law. The TI cannot be less than the authorized capital, and therefore, the actual size of the authorized capital is defined at the stage of filing an application for registration of the company. The investor claims the amount of the planned investments, and the registration authority determines the amount of authorized capital (for example, when the TI is up to 3 million dollars, the authorized capital will amount to $7 / 10$ from the TI; when the TI is from 3 to 10 million dollars, the authorized capital will not be less than $1 / 2$; with the TI from 10 to 20 million dollars - not less than $2 / 5$, etc.). For this reason, the Russian-Chinese joint ventures currently exist mainly at the level of major international projects, involving state-owned enterprises. Similar joint ventures may get bilateral tax preferences.

The most optional choice is a company with $100 \%$ foreign participation (WFOE). The main advantages of the WFOE is independence in decision-making, official possibility of doing business, converting profits in any currency and displaying it outside China, possibility of engaging in the import and export operations without a license, and the ability to protect intellectual property rights. However, the WFOE is strictly limited in the kinds of economic activities and cannot work in the areas that are not specified in the certificate of registration. Violations are punishable by fines or closure of the company.

The China's stringent bureaucratic legislation, which is artificially bureaucratic in many respects, sharply contrasts with the regulations in force in the territory of the special economic zones (SEZ), which include free economic zones (FEZ), export processing zones (or bonded zones), and experimental trade zones. These are territories of increased liberalization of laws, where tax and administrative stimuli are effectively applied. For example, a foreign company can get refunds on the export VAT only in the case of registration on the territory of the SEZ. The return rate ranges from 12 
to $17 \%$. Moreover, in the first year of its operation the company shall be exempt from the income tax; for the second and third years, the rate is reduced to half - up to 7.5\%; for the next four-ten years, the rate is $15 \%$ (the rate for the rest of China can amount to $45 \%$ ). The process for registering a new company is maximally simplified and takes from one to one and a half weeks, while throughout the whole territory it can last from six months to one year.

In fact, the entire focus of the SEZ is on the foreign capital invested in the country. This design makes it easier to control the activities of foreign investors and allows for using the attracted investments for public purposes. Currently, the SEZs are the starting points on the map of the new Silk Road.

\section{Acknowledgment}

The work was supported by the Russian Foundation for Basic Research, contract № 17-22-21001.

\section{References}

Della Porta D., Keating M. (2008). Approaches and Methodologies in the Social Sciences, Cambridge University Press, 198-221.

Guoshuihan (2002). General taxpayers VAT accreditation management approach. State Administration of Taxation. See also URL http://www.gov.cn/flfg/2010-03/05/content_1548021.htm.

GWA (2013). Chinese tax system. Greatway Advisory. See also URL http://www.gwa-asia.com/ admin/upload/China\%20s\%20tax\%20system\%20Overview.pdf. PDF file.

Paulin J. (2014). 20 Years of Success in China. Learn Chinese Business. See also URL http:// learnchinesebusiness.com/2014/03/12/interview-jx-paulin-20-years-of-success-in-china.

Shenzhen State tax letter (2012). Notice of Shenzhen National Tax on Recognition. Shenzhen National Tax Office. See also URL https://wenku.baidu.com/view/ea4e3530ee06eff9aef8078a.html.

Walk K. (1998). How to Write a Comparative Analysis. The Writing Center at Harvard University. See also URL https://writingcenter.fas.harvard.edu/pages/how-write-comparative-analysis.

Zdorikova A. (2016). How to open a company in China? laowai.ru. See also URL https:// laowai.ru/kak-otkryt-firmu-v-kitae-i-stoit-li-eto-delat. 